\title{
NATURAL AND ANTHROPIC IMPACT ASSESSMENT ON BIOCHEMICAL AND HISTOPATHOLOGICAL BIOMARKERS OF FISHES AND INVERTEBRATES AT COASTAL REGION OF ADMIRALTY BAY - KING GEORGE ISLAND
} http://dx.doi.org/10.4322/apa.2014.009

\author{
Edson Rodrigues ${ }^{1}$, Lucélia Donatti', Gannabathula Sree Vani', Helena Passeri Lavrado³, Flávia Sant'Anna Rios², \\ Cecília N.K. Suda ${ }^{1}$, Cláudio Adriano Piechnik2, Cíntia Machado², Edson Rodrigues Júnior², \\ Mariana Feijó de Oliveira', Flávia Baduy Vaz da Silva², Luciana Badeluk Cettina ${ }^{2}$
}

'Laboratório Bioquímica e Ecofisiologia de Organismo Antárticos, Universidade de Taubaté, Taubaté, SP, Brazil ${ }^{2}$ Laboratório de Biologia Adaptativa, Departamento de Biologia Celular, Universidade Federal do Paraná, Curitiba, PR, Brazil ${ }^{3}$ Laboratório de Benthos, Instituto de Biologia, Universidade Federal do Rio de Janeiro, Rio de Janeiro, RJ, Brazil e-mail: edsonrod@unitau.br, rodedson@gmail.com

Marine environments near the scientific stations and local anchoring of ships are considered potential pollution sites in Antarctica. Human waste, the burning of fuel oil and its possible leakage from ships during transport to the stations are major sources of pollution. The metabolic responses and histopathology of fish and benthic invertebrates of Admiralty Bay, King George Island, are a part of environmental monitoring research proposed in Module 3 INCT-APA for the region. The Antarctic fish Notothenia rossii and Notothenia coriiceps and invertebrates Nacella concinna were selected as target organisms for studies of biomarker responses during the XXVIII Brazilian expedition to Antarctica. The aim of these studies is to establish a baseline for biochemical and histopathological biomarkers and to understand, through bioassays, the effect of pollutants on biological responses of Antarctic organisms. Bioassays with pollutants (fuel oil, sewage and heavy metals) aim to distinguish the biological responses caused by seasonal variations in natural environmental conditions from those imposed by the presence of pollutants in Admiralty Bay ASMA.

In aquatic environments, the absorption of toxic substances, mainly by phytoplankton and zooplankton, results in the high concentration of these substances in organisms belonging to higher trophic levels in the food chain.
These substances then eventually reach a large number of organisms, including fish and invertebrates. Through the use of different biomarkers it is possible to detect the presence of pollutants in water and sediment, in the organisms that inhabit these environments.

Fish and invertebrates are good bioindicators of environmental quality in aquatic ecosystems, since they occupy different positions in the food chain and have varying spatial distribution. These features allow for a direct and indirect evaluation of the health of several components of the aquatic environment.

Using histopathological, cellular, biochemical and molecular analysis, the health of fishes and invertebrates, collected directly from nature or through the bioassays, can be evaluated. The histology can be used as a tool for identifying biomarkers of fish fauna and invertebrates.

The lesions detected in cells, tissues or organs exposed to pollutants represent an integration of the cumulative effects of these substances at the biochemical and physiological levels (Meyer et al., 2002).

Biomarkers are not normally associated with severe adverse effects caused by toxic stress agents. The early biomarker response is much more important as a marker of future adverse biological effects than as an indicator of serious environmental problems. The effects caused by toxic stress agents are often compensated or repaired at the molecular level, without compromising the higher 
level of biological performance of the organism (Lam and Gray, 2003).

Considered the best preserved region of the planet, pollution in Antarctica is restricted to areas surrounding the scientific stations and places frequented by research ships and tourists (Kennicutt II, 1995). The wreck of Paradise Bay in 1989 and the leakage of 600,000 liters of fuel oil and the subsequent contamination of the organisms in the subtidal and intertidal zone with hydrocarbons, highlights the risk of pollution from the sinking ships (Kennicutt II et al., 1992).

The stress effects of pollutants on the metabolism of fish and invertebrates have been used as biomarkers of anthropogenic activity in monitoring projects (Regoli et al., 2002; van der Oost et al., 2003).
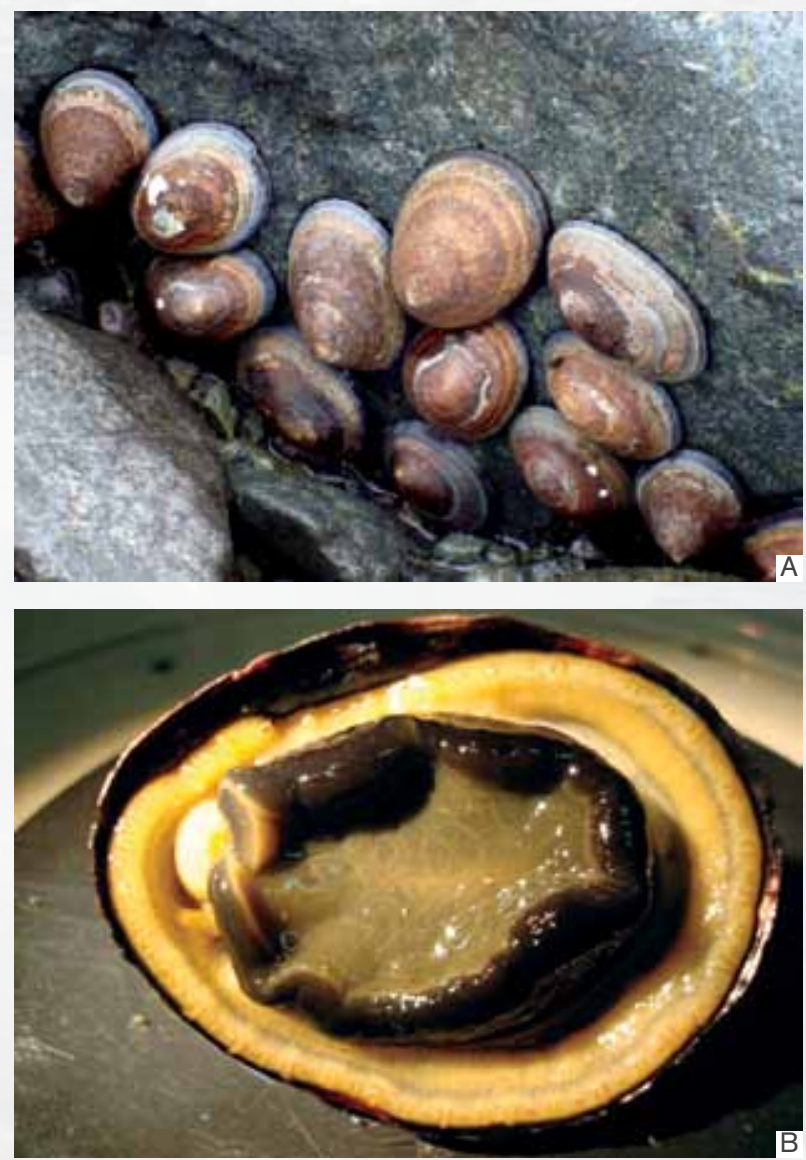

The Antarctic Specially Managed Area (ASMA) of Admiralty Bay is formed by glaciers and narrow bays, similar to the fjords, and occupies a total area of $362 \mathrm{~km}^{2}$ (ArigonyNeto et al., 2004). During the summer, several species of birds and marine mammals migrate to these places for reproduction. This area also houses three scientific stations, two with ongoing activities throughout the year, including the Brazilian station Comandante Ferraz.

The field activities of the biomarker team were initiated during the summer of XXVIII Brazilian Antarctic Expedition (November 2009 - March 2010).

Gills and foot muscle of the limpet $N$. concinna were collected as part of biomarker studies of the costal intertidal zones (Figure 1).

Further, samples of biological fluids (blood and bile) and tissues (liver, epaxial muscle, brain, kidney and gills) were
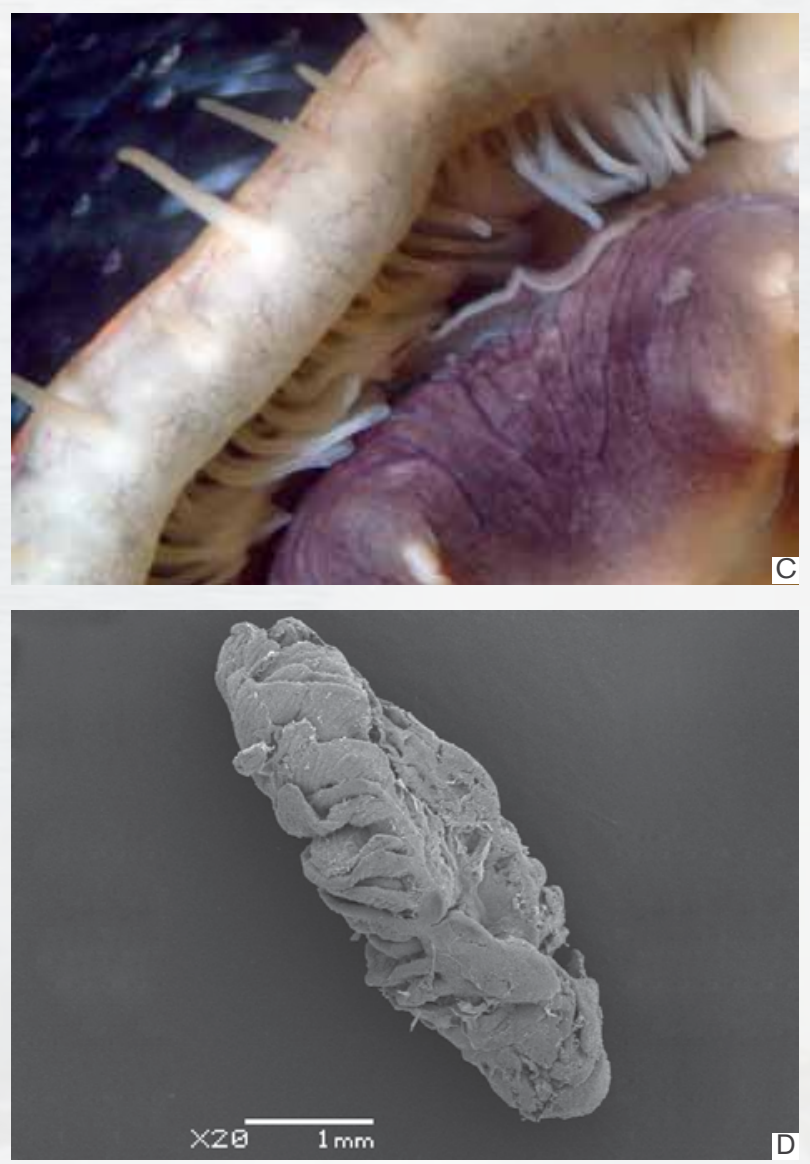

Figure 1. Nacella concinna occurs in patches in the intertidal zone (A). The foot muscle (B) and gills (C) were obtained by dissection. The scanning electron microscopy (D) showed the respiratory lamellae. 



Figure 2. Obtaining $N$. coriiceps tissues for morphological and biochemical analysis.

collected from the Antarctic fish N. coriiceps and N. rossii (Figure 2) as part of biomarker studies of the subtidal.

In both cases, tissues and fractionated biological fluids (plasma and bile) were collected, and frozen immediately in liquid nitrogen. For histopathological analysis, tissues were fixed in Alfac or in Karnovisky.

All biological material was transported to our laboratories at the University of Taubate and the Federal University of Paraná.

The sampling sites (Figure 3) were selected based on their proximity to pollution sources, penguin colonies and large areas without human and/or ornithogenic influence.

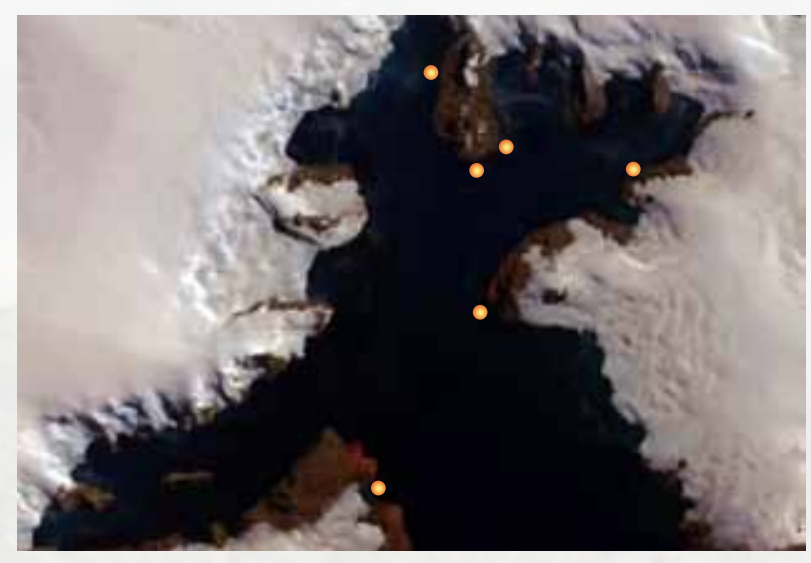

Figure 3. Sampling sites of fishes and limpets at Admiralty Bay King George Island. 
These initial studies were conducted to establish the natural levels of major biochemical biomarkers (enzymes of energy metabolism, antioxidant defenses, xenobiotic metabolism and osmoregulator responses) and histology (normal morphological patterns) in tissues of N. rossii, N. coriiceps and N. concinna, as a baseline for monitoring the Admiralty Bay ASMA.

The activities of hexokinase (HK), glycogen phosphorylase (GPAs), enolase (ENO), phosphofructokinase (PFK), lactate dehydrogenase (LDH), citrate synthase (CS) and malate dehydrogenase $(\mathrm{MDH})$ are being determined as potential markers of energy metabolism; gill ATPase $\mathrm{Na} / \mathrm{K}$ as a marker for osmoregulation response; etoxyresorufindietilase (EROD) and glutathione-S-transferase as markers of stage I and II metabolism of xenobiotics, respectively, glucose6-phosphate dehydrogenase (G-6-PDH), superoxide dismutase (SOD) and catalase (CAT) as markers of antioxidant defense, arginase (ARG) as a marker of the metabolism of nitric oxide, polyamines and phospho-Larginine. The high-pressure chromatography (HPLC) of bile, to be done at IOUSP, will also establish the hepatic excretory profile for the xenobiotic metabolism.
In tissues, hyperplasia, fusion, aneurysm and gill epithelium detachment are some of the changes that will be analyzed. Further, the fish hepatic tissue will be examined for, melano centres - macrophages, necrosis foci, leukocyte infiltration and vacuolization, among others (Mallatt, 1985; Roberts, 2001). This is because the liver is an important organ in toxicology studies. This organ performs many vital functions in animals, among them the detoxification of the body, with the biotransformation of xenobiotics (Hinton and Laurén, 1990).

Gills, in turn, are a way for the soluble xenobiotics action (Stentiford et al., 2003); they are in direct contact with the environment and any damage to their structure may interfere with respiration and ionic homeostasis (Van Den Heuvel et al., 2000).

Initial Histological studies of the livers of N. rossii and $N$. coriiceps revealed that hepatocytes have a polyhedral shape, with single central spherical shaped nucleus with one or more nucleols. The predominant chromatin in the hepatocyte nuclear region is euchromatic and is widely dispersed. The heterochromatin concentration is much less and appears only is some nuclear regions. The hepatic tissue has vessels of many different sizes, distributed in the
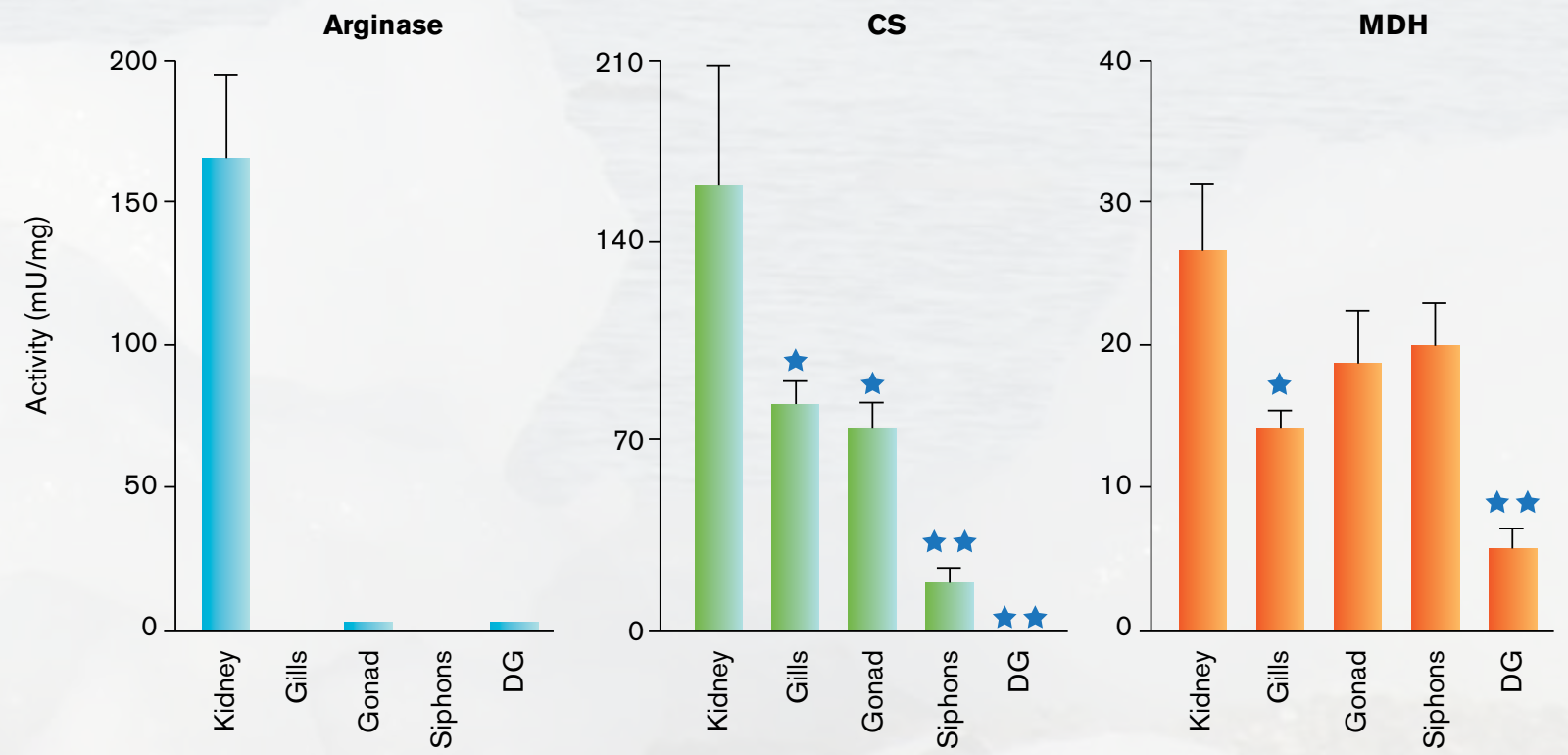

Tissues

Figure 4. Tissue levels of the enzymes arginase, citrate synthase and malate dehydrogenase for the bivalve L. elliptica (Rodrigues et al., 2009). 

KENNICUTT II, M. C. et al. Hydrocarbon contamination on the antarctic peninsula. I. Arthur Harbor - subtidal sediments. Marine Pollution Bulletin, v. 24, p. 499-505, 1992.

LAM, P. K. S.; GRAY, J. S. The use of biomarkers in environmental monitoring programmes. Marine Pollution Bulletin, v. 46, p. 182-186, 2003.

MALLATT, J. Fish gill structural changes induced by toxicants and other irritants: A statistical review. Canadian Journal of Fisheries and Aquatic Sciences, v. 42, p. 630-648, 1985.

MEYER, B. et al. Seasonal differences in citrate synthase and digestive enzyme activity in larval and postlarval Antarctic krill, Euphausia superba. Marine Biology, v. 141, p. 855-862, 2002.

REGOLI, F. et al. Oxidative stress in ecotoxicology: from the analysis of individual antioxidants to a more integrated approach. Marine Environmental Research, v. 54, p. 419-423, 2002.

ROBERTS, R. J. Fish Pathology. 3rd ed. London: Churchill Livingstone, 2001.

RODRIGUES, E. et al. Arginine metabolism of the Antarctic Bivalve Laternula elliptica (King \& Broderip, 1831): an ecophysiological approach. Polar Biology, v. 32, n. 5, p. 691-712, 2009.

RODRIGUES, E.; SREE VANI, G.; LAVRADO, H. P. Nitrogen metabolism of the Antarctic Bivalve Laternula elliptica (King \& Broderip) and its potential use as biomarker. Oecologia Brasiliensis, v. 11, p. 37 - 49, 2007.

STENTIFORD, G. D. et al. Histopathological biomarkers in estuarine fish species for the assessment of biological effects of contaminants. Marine Environmental Research, v. 55, p. 137-159, 2003.

van den HEUVEL, M. R. et al. Disease and gill lesions in yellow perch (Perca flavescens) exposed to oil sands miningassociated waters. Ecotoxicology and Environmental Safety, v. 46, p. 334-341, 2000.

van der OOST, R.; BEYER, J.; VERMEULEN, N. P. E. Fish bioaccumulation and biomarkers in environmental risk assessment: a review. Environmental Toxicology and Pharmacology, v. 13, p. 57-149, 2003. 